\title{
A Re-Examination of the Relationship between Foreign Flows and Economic Growth in LLDCs: Dynamic Fixed Effects (DFE)
}

\section{Faruq Umar, Quadri}

Innovation and Technology Policy Department (ITPD), Nigerian Institute of Social and Economic Research (NISER), Ibadan, Nigeria.

Email: qufaruq@gmail.com Tel:+2348053655874

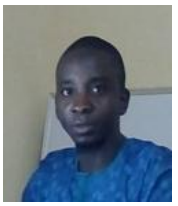

\begin{abstract}
There are 32 landlocked developing countries (LLDCs) across four major continents of the world. These countries are mostly low-income or lower middle-income developing economies and suffer from a number of challenges especially, dwindling economic growth. The main objective of the study therefore, is to re-examine how economic growth in LLDCs can be influenced with the aids of foreign flows such as foreign direct investment (FDI), foreign portfolio investment (FPI) and official development assistance (ODA). The study made use of a sample of 19 member-states due to data limitation in order to evaluate the impact of foreign flows on economic growth using ARDL panel approach with the Dynamic Fixed effect (DFE) as the baseline estimation techniques during the period of 1995 to 2017 . Our finding reveals that in the long-run, net FDI and net ODA have impacts on the economic growth in LLDCs but net FPI shows no any discernible impacts on GDP growth in LLDCs.
\end{abstract}

Keywords: Landlocked developing countries (LLDCs), Co-integration, Dynamic fixed effect (DFE), Economic growth, FDI, FPI, ODA. JEL Classification: F4; C23; F2 1; F35; F24; F29.

Citation | Faruq Umar, Quadri (2019). A Re-Examination of the Relationship between Foreign Flows and Economic Growth in LLDCs: Dynamic Fixed Effects (DFE). Asian Journal of Economics and Empirical Research, 6(2): 169-179.

History:

Received: 13 August 2019

Revised: 17 September 2019

Accepted: 21 October 2019

Published: 2 December 2019

Licensed: This work is licensed under a Creative Commons

Attribution 3.0 License (co)

Publisher: Asian Online Journal Publishing Group
Funding: This study received no specific financial support.

Competing Interests: The author declares that there are no conflicts of interests regarding the publication of this paper.

Transparency: The author confirms that the manuscript is an honest, accurate, and transparent account of the study was reported; that no vital features of the study have been omitted; and that any discrepancies from the study as planned have been explained.

Ethical: This study follows all ethical practices during writing

\section{Contents}

1. Introduction

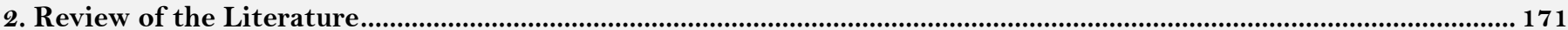

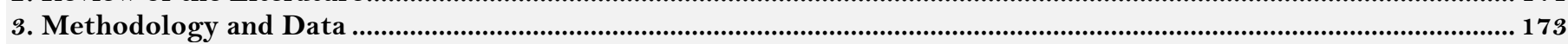

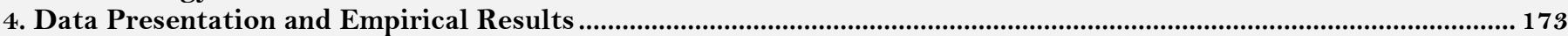

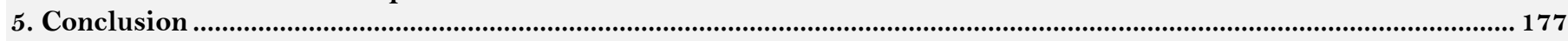

References 


\section{Contribution of this paper to the literature}

This study contributes to the existing literature by examining how economic growth in LLDCs can be influenced with the aids of foreign flows such as foreign direct investment (FDI), foreign portfolio investment (FPI) and official development assistance (ODA).

\section{Introduction}

In the developing countries, flows of foreign capital in their various forms have become the alternative source to deficits in domestic saving as well as dwindling foreign exchange earnings to meet demand for investments and other financial obligations. These foreign flows in their different forms viz-a-viz; foreign direct investment, foreign portfolio investment, official development assistance, foreign remittances, as well as external debts, have varying degrees of macroeconomic impacts on the economic growth and development of the destination countries. Bearing on this importance of foreign capital flows into the developing economies of the world, quite a few anecdotal research work have examined the causality between foreign capital flows and economic growth at a single-country level as well as cross-countries. A number of empirical research work on the efficacy of international capital influx have tried to examine whether these capital flows in its various forms have achieved its main targets of enhancing ordinary consumers' welfare and economic growth of developing economies such as that of these landlocked developing countries (LLDCs). There are plethora of evidences in the literature that when researchers examined the basic reason behind foreign capital influx, improvement in the level of welfare and accelerated growth in the economy, divergent findings are often reported by researchers depending on the adopted methodology. For instance, a number of work adopting the cost-benefit approach at the micro-level often arrive at the findings that foreign capital flows have been effective in achieving its fundamental objectives. In contrast, the macro-level approach, namely cross-country regression analyses, are oftentimes not definite and conclusive. This contradiction, according to Mosley (1986) is dubbed the "micro-macro paradox.

In another dichotomy, the findings of these studies have shown a diverse opinions (Ilhan, 2007). However, according to Agbloyor et al. (2014); Durham (2004); Akinlo (2004) and Adekunle and Sulimon (2018) there are some researchers who opined that foreign capital flows are likely to accelerate growth in the economies only if these developing countries possess the necessary requisites viz-a-viz a conducive political atmosphere, sophisticated infrastructural facilities, improved technology, stock of human capital rather than mere population size as well as a well-functioning and deepened financial system; to absorb and make efficient utilization of these flows. On the other hand, some other authors have discovered that foreign flows impacted differently across several constituents of the flows Orji et al. (2014). Meanwhile, the contradiction in the findings of these two classes of authors is perhaps, according to Obiechina and Ukeje (2013) attributable to relative volatility between portfolio flows and FDI flows.

Generally speaking, Adekunle and Sulimon (2018) assert that fluctuation of capital flows does not occur predominantly at the preceding period of economic recession but during and accompanying periods of the economic turmoil. Besides, fluctuation of foreign flows is a rife phenomenon associated with developing economies with no strong and competent financial structures to make effective use of the flows during financial crunch.

The essence of foreign capital flows to the growth trajectory of the emerging economies remains an issue of fierce argument among economists as well as international policy makers. Foreign capital flows in its variants remain an essential thematic issue in international economics discuss given its implications on the amelioration of absolute and relative poverty in developing countries. Mixed findings have been discovered from previous databased researches on foreign capital flows and economic growth. Gomanee et al. (2003); Dalgaard et al. (2004) and Karras (2006) for example, discovered a positive relation between economic growth and foreign capital flows; while Burnside and Dollar (2000) and Bräutigam and Knack (2004) on the other hand, reported a negative relation between foreign capital flows and growth. According to Mosley et al. (1987) and Boone (1996) capital flows has no effects on growth of the economy. It is worth note that Burnside and Dollar (2000) arrived at the submission that foreign capital flows has positive impacts on growth. Meanwhile, the relevance of their conclusion is only to economies with effective trade policies as well as fiscal and monetary policies.

Thus, the key objective of this research paper is to re-evaluate of the existing relations between foreign flows and economic growth in the landlocked developing countries (LLDCs). The paper endeavors to provide answers to the following research questions viz-a-viz: what is the impact of foreign direct investment (FDI) on economic growth in the LLDCs? Does foreign portfolio investments (FPI) significantly affect economic growth in the LLDCs? And finally, how has official development assistance (ODA) accelerated growth in the LLDCs' economies?

Methodologically, this paper tries to be distinct from a number of other research works in its adoption of Autoregressive Distributed Lag (ARDL) within the Panel framework which seems to have not be exhaustively used to investigate the effects of foreign flows on economic growth. A number of research work such as Akinlo (2004); Kolawole (2013); Jibir and Abdu (2017); Obiechina and Ukeje (2013); Ugwuegbe et al. (2016) have adopted ECM or VECM as appropriate to gauge the effects of foreign capital flows on economic growth. The studies highlighted above only centered on Nigeria as their area of study. It is equally observed that many of the work used only foreign direct investment (FDI) as the representative of capital flows, but for Ugwuegbe et al. (2016) who used external borrowing and official development assistance (ODA) in lieu of foreign direct investment (FDI). Many other authors have adopted methodological frameworks such as ordinary least squares (OLS), three-stage least squares (3SLS), vector auto-regression (VAR) and Toda-Yamamoto (T-Y) causality test. Also some surveys such as Nyeadi et al. (2014); Adeleke (2014) and Shen (2010) adopted cross-country analyses, with Nyeadi et al. (2014) diagnosing each country under separate analysis while Adeleke (2014) and Shen (2010) investigating the economies in a panel framework and estimated pooled OLS, fixed-effects and random-effects models for their studies just to arrive at reliable and valid analyses.

This introductory section of the study is centered on background to the study. Follows by section 2 which focuses on the literature review that takes a look at some theoretical underpinnings and empirical findings. Sections 3 and 4 discuss the methodology and empirical results respectively. Finally, the concluding part of the paper is the focus of section 5 . 


\section{Review of the Literature}

The Two-gap model of foreign aids, according to Chenery and Strout (1966), is centered on the essence of attracting foreign flows, most importantly foreign aids, to bridge the two gaps of savings and foreign exchange. They opined that the first gap, savings, is the shortage of domestic savings over domestic investment opportunities thereby making investments to be constrained by the available foreign exchange. The second gap on the other hand; foreign exchange gap occurs when a country's foreign exchange supply via its import demand and outflows of capital investment exceeds its export supply and inflows of capital investment from its trading partners. The Harrod-Domar growth model equally supports the Two-gap model of Chenery and Strout (1966) by propounding that economies with excess investment requirements relative to domestic savings would possibly bridge the socalled investment-savings gap by pursuing foreign capital in form of foreign aids or foreign private investment (Todaro and Smith, 2012). The Harrod- Domar growth model posits a positive relations between economic growth and savings but a negative relations between output growth and capital-output ratio.

Meanwhile according to the Solow growth model, in the short-run, closed economies associated with higher savings rate, ceteris paribus, grow faster than those with lower savings rates and tend to diverge from lower income levels per person. But for an open economies, the model asserts that as capital flows from industrial countries with increased capital-labor intensity and lower returns on investment to poor countries with lower capital-labor intensity and higher returns on investment, the economies undergo output convergence at superior levels of incomes (Todaro and Smith, 2012). Another interesting part of endogenous growth models is their ability to analyze abnormal foreign influx of capital that widens income gap between the industrialized and poor nations. The opportunity of higher investments' returns associated with non-industrialized economies due to lower capitallabor intensity, according to Todaro and Smith (2012) are denied by discouraging rate of substituting investments in human resources (health and education), infrastructural facilities as well as research and development (R\&D). Hence, contrary to the neoclassical growth models, models of endogenous growth propose an operational function for public policy in catalyzing economic growth via comprehensive investments in the formation of human capital and the impetus for foreign investments in technical knowhow-driven industries, such as telecommunications and Artificial Intelligence (AI).

\subsection{Empirical Findings from the Developing Economies}

In his study of the causal relations between economic growth and trade openness and financial development in Nigeria; Chimobi (2010) divided the financial variables into three sub-classes of variables which are private credit, money supply and direct credit. He used time series data ranging from 1970 to 2005. Testing the stationary of the variables, the Augmented Dickey Fuller (ADF) test was adopted and his findings revealed that all the variables were I(1). That is, they were all stationary after first difference. For the long run equilibrium, no co-integration was found among the variables and the Granger causality test shows that there is no causal relations between the explanatory variables and economic growth. Surprisingly, he found that economic growth affects financial development and trade openness in Nigeria.

Foreign direct investments (FDI), in line with Gray (2003) are seen as an origin of useful technologies and skills in the long term. At the tail end of the 2008 Financial Crunch, he discovered that FDI emerged as an essential variable imparting on Indonesia's economic growth. Gray investigated FDI with how its flows was of great assistance in Indonesian economy. Development projects in Indonesia were found to be uncertain for businessmen and a number of challenges were equally discovered between governments at various levels in Indonesia.

In his study, Ouattara (2006) looks at the impacts of foreign capital supply on fundamental fiscal variables in Senegal. He made used of information ranging from the period of 1970 to 2000 and his attention was majorly on the causalities between capital flows and debts. He came up with the following three findings. In the first instance, he discovered that roughly $41 \%$, the largest part of capital flows, are used in debts financing in Senegal while $20 \%$ of the state's revenue are committed to debt servicing. Secondly, he discovered that the foreign capital supply has statistically insignificant impacts on domestic expenditures, and finally, domestic expenditure was significant negative affected by debt servicing. He therefore, concludes that a decrease in debt should be a more potent policy instrument to receiving more loans. In a panel study of seven countries in the East Asia, Mandilaras and Popper (2009) take a look at foreign capital flows. Their main objective was to determine the factors that have influence on net capital outflows. Their evaluation include the effect of openness of financial sector on external capital flows as well as the relations between domestic and foreign capital flows in the these countries. They found that domestic capital sector serve as a perfect yardstick in measuring the changes in aggregate capital supplies in the seven chosen countries. They equally discovered that lack of closeness of the capital sector is vital in explaining aggregate capital flows in the seven East Asian countries. Surprisingly, the US macroeconomic fundamentals were found to be significant determinants of the GDP growth in these countries. Addison et al. (2005) observe projections in formal capital flows to Africa for the period between 1960 and 2002. The authors discovered a significant decrease in foreign flows to these economies in the last few years which has greatly led to a rise in the magnitude of poverty in Africa and economy of the region as a whole has suffered. They discovered that the shortage in capital flows would make the achievement of the MDGs much harder if not impossible. And then concludes that foreign capital flows do in real sense accelerate economic growth and also leads to a reduction in impoverishment. In addition, foreign capital flows directly affects public sector aggregates, enhancing increased public expenditure and reduction in domestic borrowings. To achieve MGDs, it is crystal clear that advantages of sources of innovation for financial deepening and widening combining with development capital supply must be taken. Hoang et al. (2010) adopted panel data ranging from 1995 to 2006 to examine the effects of FDI on economic growth rates in Vietnam. They found that FDI has significant impact on economic growth in Vietnam and that a 1 per cent rise in FDI will expand economic growth by 0.012 per cent. Hoang et al. (2010) discover that effects of FDI is only positive on the stock of human capital after a given threshold level. They thus, concluded that only at this point can a country tap the advantages embedded in FDI. 


\subsection{Empirical Findings from the Developed Economies}

In Portugal, Andraz et al. (2009) used a 3-stage approach with data ranging from 1977 to 2004 to find that FDI inflows and economic growth have a bi-directional causality. The main aim of their study was to observe Grangercausality between the macroeconomic variables of GDP, FDI and export. They thus, discovered that FDI was significant in short run and granger-caused aggregate real exports. It is equally found that FDI is one of the economic fundamentals that impact on growth of GDP in Portugal. Meanwhile, real export do not influence increment in GDP while increase in FDI impacts total capital formation in Portugal. Therefore, they conclude that increased capacity of total output and foreign competitiveness would increase the rates at which economy grows.

Adhikary (2011) reports that the relations between capital formation and economic growth, trade openness, foreign direct investment (FDI) appears to be positive. Karras (2006) looked into the relations between foreign aid and growth of GDP per capita with datasets ranging from 1960 to 1997 for a sample of 71 non-industrial economies in quest for aid and opined that a positive and statistically significant impact originates from foreign aid to economic growth.

Gomanee et al. (2005) directly examined the channels by which aid impacted on economic growth. In their paper they made use of a sample of 25 Sub-Saharan African countries from 1970 to 1997 and then arrived at the conclusion that foreign aid has a significant positive impact on economic growth in these economies. Investment was discovered as the most effective transmission mechanism and that poor growth profile in Africa need not be completely attributed to aid ineffectiveness. Quartey (2005) utilized huge volume of data to examine the methods of innovations to make financial aid effectual in Ghana and concludes that the state and its development partners must propose a better and well-coordinated plan to make multi-donor budgetary support successful. He also recommended that the state should work towards reducing its volume of debt to avoid using the bulky of these aids for debt servicing. According to Burnside and Dollar (2000) the connections between aid, state policy, and economic growth showed that foreign aid has little or no significant impact on the economies with weak economic policies but a positive impacts on growth in non-industrial countries with strong fiscal, monetary and trade policies.

\subsection{The Challenge of Economic Transformation of LLDCs}

There are 32 landlocked developing countries (LLDCs) distributed across four continents as shown in Table 1 below. These countries are majorly low-income or lower middle-income developing economies and suffer from a number of challenges especially, dwindling economic growth. These economic growth challenges of LLDCs are compounded by the constraints of lack of entrance to the sea, geographical remoteness, and poor physical infrastructure. As rightly captured by a recent statement on the plight of LLDCs, though LLDCs are diverse with respect to economic systems, natural resource endowment and levels of development, these common set of challenges impose on them rising transaction and transport costs which make attainment of global economic competitiveness an arduous task. The high transaction and transport costs restricts trade, make manufacturing in LLDCs more expensive thereby preventing real sector investments required for structural economic transformation, and hinders the regular productivity improvements that move countries up in the global value chains.

Table-1. List of landlocked developing countries by regions.

\begin{tabular}{|c|c|c|c|c|c|}
\hline \multicolumn{2}{|l|}{ Africa } & \multicolumn{2}{|l|}{ Asia } & \multirow{2}{*}{$\begin{array}{l}\text { Europe } \\
\text { Armenia }\end{array}$} & \multirow{2}{*}{$\begin{array}{l}\text { South America } \\
\text { Bolivia }\end{array}$} \\
\hline Botswana & Mali & Afghanistan & Mongolia & & \\
\hline Burkina Faso & Niger & Bhutan & Nepal & Azerbaijan & Paraguay \\
\hline Burundi & Rwanda & Kazakhstan & Tajikistan & Moldova & \\
\hline Central Africa Republic & South Sudan & Kyrgyzstan & Turkmenistan & North Macedonia & \\
\hline Chad & Eswatini & Lao PDR & Uzbekistan & & \\
\hline Ethiopia & Uganda & & & & \\
\hline Lesotho & Zambia & & & & \\
\hline Malawi & Zimbabwe & & & & \\
\hline
\end{tabular}

Source: UN-OHRLLS.

LLDCs also exhibit major challenges in the area of information and communication technologies (ICTs) infrastructure, which remain relatively less developed in spite of its crucial role as a driver of network relationships for trade facilitation and integration into the global economy. ICTs are especially important for overcoming the constraints due to remoteness by facilitating access to information on global markets for producers and consumers; and they also promote technology transfer required for productivity growth and unlocking the economic potentials of the LLDCs.

The challenge of land-locked compel most LLDCs to depend on their neighboring transit countries to access international market. This kind of reliance is classified into four in the literature: reliance on neighbors' infrastructure; dependence on sound cross-border political relations; reliance on neighbors' peace and stability; and dependence on neighbors' administrative practices.

Many of these landlocked developing countries are besides, highly commodity dependent, and their export is majorly heavy and low value goods which often lead to high transport costs. Primary goods dominated over 50 per cent of the exports of 27 out of the 32 LLDCs in 2011-2013. This implying that non-industrial and semi-processed commodities contributed roughly 75 per cent of the aggregate goods and services exported out of the LLDCs economies as whole. In the same timeframe, 84.7 per cent is the average proportion of exports contributed by primary goods in the LLDCs. The vulnerability of LLDCs due to geographical remoteness and dependency thus hinders the economic transformation and results in different sets of crises and priorities in each of the countries. Moreover, the locational challenges of LLDCs are usually made complex due to weak transit-transport infrastructure, poor customs operations, and over-reliance on exports of non-industrial commodities (Rothstein, 2015). 
In view of the foregoing constraints on economic transformation in LLDCs, the United Nations recognized that the achievement of the global development goals of eradicating poverty, inclusive growth, and environmental sustainability would be impossible in LLDCs without a joint action by the international community to address the challenge of land-locked.

\section{Methodology and Data}

In this research work, non-primary data are strictly used. It relied on annual time series data from 19 selected countries out of the 32 LLDCs due to data constraints and they were solely collected from the World Bank, WDI (2018). The variables selected for the study include net foreign direct investment, net portfolio investment and net official development assistance as the explanatory variables while the explained variable is real GDP per capita.

\subsection{Specification of Model}

In line with the cross-country regression analysis provided by Hansen and Tarp (2000) a single-equation regression is deemed fit to achieve the research objectives because of its frequent use in the literature.

It is imperative to know that for in short panels, homogeneity of slope coefficients and stationary are assumed. However, for long panels, the assumption of stationary and homogeneity of coefficient of the slopes are often not appropriate. Hence, the consideration of both non-stationary and heterogeneity when dealing with long panels. According to Pesaran and Smith (1995) and Pesaran et al. (1999) a panel data representation of the time series autoregressive distributed lag (ARDL) model is required to account for any potential non-stationary in the model. $P C G_{i t}=\rho\left(P C G_{i, t-1}\right)+\beta_{1}\left(F D I_{i t}\right)+\beta_{2}\left(F P I_{i t}\right)+\beta_{3}\left(O D A_{i t}\right)+\mu_{i}+\varepsilon_{i t}$

$i=1, \ldots, N ; t=1, \ldots, T$.

$k=1, \ldots, p ; j=0,1, \ldots, q$.

Where $\mu_{i}$ is the group-specific effect; $i$ is the number of groups; $t$ is the number of periods; $P C G_{i t}$ represents per capita GDP growth rate, $O D A_{i t}$ denotes official development assistance relative to GDP, $F D I_{i t}$ is foreign direct investment relative to GDP and $F P I_{i t}$ is net foreign portfolio investment relative to GDP, $\tau_{t}$ represents time period effects.

We can re-write the model in a way that permits for the determination of both long run and short run estimates as follows:

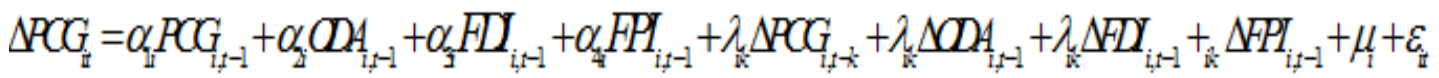

$$
\begin{aligned}
& i=1, \ldots, N ; t=1, \ldots, T \text {. } \\
& k=1, \ldots, p ; j=0,1, \ldots, q \text {. }
\end{aligned}
$$

\subsection{Method of Panel Co-Integration}

Adopting method of panel co-integration is substantiated by considerations that include magnitude and features of the data utilized.

The traditional panel techniques of random effect $(\mathrm{RE})$ and fixed effect $(\mathrm{FE})$ is considered most appropriate for microeconomic datasets such as surveys with small $\mathrm{T}$ and large N. Meanwhile, spurious result is often generated with the analysis of panel data with $\mathrm{T}>\mathrm{N}$ because the behavioral properties of the data tends to be close to the of a time series. This spuriousness arises while dealing with macroeconomic data in the nature of this research work, for the fact that macroeconomic variables are often non-stationary.

Dealing with difficulties that often result from gathering of observations over time, Baltagi (2008) proffers two alternatives: non-homogeneous regressions for each individual to bypass the homogeneity of the parameters that would result from a single regression and; the adoption of time series processes to panels to deal with nonstationary and co-integrations within the variables of interest. Panel co-integration is noteworthy as an extension of time series analysis to panel data with large time $(\mathrm{T})$.

According to Pedroni (2000); the panel co-integration technique offers both the short and long run estimates and also has power to pool long run equilibrium involved in panels, by permitting short run dynamics and fixed effect to be non-homogeneous across the panels. The procedures can be summarized as follows: the unit root test is conducted for pre-estimation investigation.

If series were discovered to be integrated of non-zero order, then there comes a need to run a co-integration test to determine the possibility of co-integrations among the selected variables. Lastly, if a long-run relations (cointegrated) is established among variables, there is need to determine the equilibrium coefficients in the long run. Like the short panels, there are essentially three estimators developed to estimate dynamic models with long panels. They are: Mean Group (MG) estimator, pooled Mean Group (PMG) estimator and the dynamic Fixed Effect (DFE) estimator.

\section{Data Presentation and Empirical Results \\ 4.1.Descriptive Analysis of the Data}

The statistical characteristics of the data including the mean, standard deviation, minimum and maximum values, at levels are depicted in this section of the paper. The descriptive statistics is to show a behavioral trend of our data and analyzed according to the sampled countries as shown in Table 2. 


\begin{tabular}{|c|c|c|c|c|c|c|}
\hline $\mathbf{S} / \mathbf{N}$ & Country & Statistics & GDP & FDI & FPI & ODA \\
\hline \multirow[t]{5}{*}{1} & Armenia & & & & & \\
\hline & & Mean & 2567.219 & 5.153161 & $-4.00 \mathrm{E}+07$ & 93.16771 \\
\hline & & St. Dev & 1092.019 & 2.643053 & $1.55 \mathrm{E}+08$ & 30.2292 \\
\hline & & Min & 1043.541 & 1.100209 & $-6.89 \mathrm{E}+08$ & 53.06903 \\
\hline & & Max & 4198.795 & 11.66114 & $8.68 \mathrm{E}+07$ & 181.9921 \\
\hline \multirow[t]{5}{*}{2} & Azerbaija & & & & & \\
\hline & & Mean & 3749.033 & 16.47968 & $-2.35 \mathrm{E}+08$ & 24.06721 \\
\hline & & St. Dev & 1964.774 & 14.8073 & $6.53 \mathrm{E}+08$ & 17.84348 \\
\hline & & Min & 1234.997 & 2.464374 & $-2.67 \mathrm{E}+09$ & -7.52166 \\
\hline & & Max & 6072.586 & 55.0759 & $3.47 \mathrm{E}+08$ & 91.82452 \\
\hline \multirow[t]{5}{*}{3} & Bolivia & & & & & \\
\hline & & Mean & 1859.194 & 4.574412 & $7.33 \mathrm{E}+07$ & 76.34275 \\
\hline & & St. Dev & 313.2728 & 3.704279 & $4.27 \mathrm{E}+08$ & 14.57843 \\
\hline & & Min & 1493.418 & -2.49888 & $-9.80 \mathrm{E}+08$ & 49.69431 \\
\hline & & Max & 2490.956 & 12.19663 & $9.32 \mathrm{E}+08$ & 106.4882 \\
\hline \multirow[t]{5}{*}{4} & Botswana & & & & & \\
\hline & & Mean & 6114.811 & 3.245471 & $3.25 \mathrm{E}+08$ & 62.06506 \\
\hline & & St. Dev & 1101.978 & 2.193433 & $4.04 \mathrm{E}+08$ & 74.1784 \\
\hline & & Min & 4525.769 & 0.558883 & $-5.34 \mathrm{E}+08$ & 16.17276 \\
\hline & & Max & 7864.253 & 8.93102 & $1.23 \mathrm{E}+09$ & 377.472 \\
\hline \multirow[t]{5}{*}{5} & Burkinafa & & & & & \\
\hline & & Mean & 525.2079 & 1.101836 & $2.54 \mathrm{E}+08$ & 51.03386 \\
\hline & & St. Dev & 96.1554 & 1.193713 & $2.24 \mathrm{E}+08$ & 14.93857 \\
\hline & & Min & 361.1214 & 0.020826 & $-1.20 \mathrm{E}+08$ & 15.48767 \\
\hline & & Max & 685.7575 & 4.103598 & $5.25 \mathrm{E}+08$ & 71.57341 \\
\hline \multirow[t]{5}{*}{6} & Eswatini & & & & & \\
\hline & & Mean & 3804.115 & 2.150596 & $-6.86 \mathrm{E}+06$ & 59.7954 \\
\hline & & St. Dev & 668.9482 & 2.837498 & $3.28 \mathrm{E}+07$ & 36.19737 \\
\hline & & Min & 2938.889 & -2.73891 & $-1.16 \mathrm{E}+08$ & 13.05902 \\
\hline & & Max & 4838.844 & 9.684826 & $4.59 \mathrm{E}+07$ & 132.3987 \\
\hline \multirow[t]{5}{*}{7} & Kahzakhs & & & & & \\
\hline & & Mean & 7395.097 & 7.740143 & $1.82 \mathrm{E}+09$ & 11.15542 \\
\hline & & St. Dev & 2619.301 & 3.467813 & $5.75 \mathrm{E}+09$ & 5.3366 \\
\hline & & Min & 3738.469 & 2.893193 & $-8.47 \mathrm{E}+09$ & 3.278675 \\
\hline & & Max & 10867.74 & 13.01286 & $1.74 \mathrm{E}+10$ & 21.57075 \\
\hline \multirow[t]{5}{*}{8} & Krygkhst & & & & & \\
\hline & & Mean & 798.6478 & 5.290868 & $7.45 \mathrm{E}+06$ & 65.70728 \\
\hline & & St. Dev & 163.8211 & 4.223879 & $2.83 \mathrm{E}+07$ & 23.74736 \\
\hline & & Min & 535.044 & -1.39184 & $-2.71 \mathrm{E}+07$ & 37.21322 \\
\hline & & Max & 1070.369 & 17.13123 & $1.29 \mathrm{E}+08$ & 129.2602 \\
\hline \multirow[t]{5}{*}{9} & Lesotho & & & & & \\
\hline & & Mean & 1042.135 & 7.938632 & $1.23 \mathrm{E}+06$ & 61.52298 \\
\hline & & St. Dev & 247.8001 & 10.14474 & $3.48 \mathrm{E}+06$ & 39.17914 \\
\hline & & Min & 739.0457 & 0.402577 & $-3.91 \mathrm{E}+06$ & 15.68031 \\
\hline & & Max & 1436.15 & 30.38665 & $1.46 \mathrm{E}+07$ & 158.0808 \\
\hline 10 & Macedon & & & & & \\
\hline & & Mean & 4032.104 & 3.903113 & $-6.12 \mathrm{E}+07$ & 94.56051 \\
\hline & & St. Dev & 754.9118 & 2.874941 & $1.85 \mathrm{E}+08$ & 28.17629 \\
\hline & & Min & 3056.985 & 0.202774 & $-6.50 \mathrm{E}+08$ & 39.73272 \\
\hline & & Max & 5256.711 & 12.65813 & $2.09 \mathrm{E}+08$ & 136.8014 \\
\hline 11 & Malawi & & & & & \\
\hline & & Mean & 429.7709 & 3.196528 & $-7.90 \mathrm{E}+07$ & 53.55073 \\
\hline & & St. Dev & 55.31789 & 3.180963 & $1.24 \mathrm{E}+08$ & 14.8628 \\
\hline & & Min & 361.0435 & -0.1474 & $-3.95 \mathrm{E}+08$ & 32.41855 \\
\hline & & Max & 512.6456 & 10.15434 & $3.97 \mathrm{E}+06$ & 85.76388 \\
\hline 12 & Mali & & & & & \\
\hline & & Mean & 647.946 & 2.529665 & $-9.65 \mathrm{E}+05$ & 57.40963 \\
\hline & & St. Dev & 76.11271 & 1.650835 & $1.37 \mathrm{E}+08$ & 17.43609 \\
\hline & & Min & 496.6702 & -0.31655 & $-3.71 \mathrm{E}+08$ & 26.31357 \\
\hline & & Max & 764.1692 & 6.351123 & $4.55 \mathrm{E}+08$ & 84.95876 \\
\hline 13 & Moldova & & & & & \\
\hline & & Mean & 1732.854 & 4.865271 & $-6.08 \mathrm{E}+06$ & 4.568708 \\
\hline & & St. Dev & 468.4432 & 3.114204 & $6.66 \mathrm{E}+07$ & 5.181362 \\
\hline & & Min & 1135.818 & 1.174877 & $-2.34 \mathrm{E}+08$ & -0.0493 \\
\hline & & Max & 2578.498 & 12.17908 & $1.40 \mathrm{E}+08$ & 16.6291 \\
\hline 14 & Mongolia & & & & & \\
\hline & & Mean & 2457.067 & 8.052962 & $-2.60 \mathrm{E}+08$ & 109.0906 \\
\hline & & St. Dev & 913.7001 & 14.76001 & $4.98 \mathrm{E}+08$ & 36.70459 \\
\hline & & Min & 1459.118 & -37.1548 & $-2.30 \mathrm{E}+09$ & 78.82101 \\
\hline & & Max & 3996.144 & 43.91211 & $1.61 \mathrm{E}+08$ & 245.3353 \\
\hline 15 & Niger & & & & & \\
\hline & & Mean & 347.6648 & 4.568708 & $-1.79 \mathrm{E}+07$ & 36.13407 \\
\hline & & St. Dev & 22.87198 & 5.181362 & $4.64 \mathrm{E}+07$ & 10.3722 \\
\hline
\end{tabular}




\begin{tabular}{|c|c|c|c|c|c|c|}
\hline & & Min & 322.7779 & -0.0493 & $-1.39 \mathrm{E}+08$ & 17.13371 \\
\hline & & Max & 393.6621 & 16.6291 & $3.02 \mathrm{E}+07$ & 55.85703 \\
\hline \multirow[t]{5}{*}{16} & Paraguay & & & & & \\
\hline & & Mean & 4089.306 & 1.2551 & $-1.51 \mathrm{E}+08$ & 15.46453 \\
\hline & & St. Dev & 561.1228 & 0.86059 & $3.09 \mathrm{E}+08$ & 6.029084 \\
\hline & & Min & 3406.233 & -0.75019 & $-1.30 \mathrm{E}+09$ & 3.89317 \\
\hline & & Max & 5272.576 & 3.692033 & $9.00 \mathrm{E}+06$ & 29.16989 \\
\hline \multirow[t]{5}{*}{17} & Tajikhstan & & & & & \\
\hline & & Mean & 644.2494 & 3.971965 & $-1.79 \mathrm{E}+08$ & 34.41881 \\
\hline & & St. Dev & 212.5096 & 3.549803 & $2.35 \mathrm{E}+08$ & 13.3113 \\
\hline & & Min & 366.9354 & 0.616866 & $-6.27 \mathrm{E}+08$ & 11.28918 \\
\hline & & Max & 1024.859 & 13.10218 & $1.19 \mathrm{E}+06$ & 57.5405 \\
\hline \multirow[t]{5}{*}{18} & Uganda & & & & & \\
\hline & & Mean & 536.4975 & 3.629608 & $-2.68 \mathrm{E}+07$ & 43.16339 \\
\hline & & St. Dev & 118.0268 & 1.294726 & $1.5 \mathrm{oE}+\mathrm{O} 8$ & 9.188309 \\
\hline & & Min & 362.1812 & 2.001792 & $-2.59 \mathrm{E}+08$ & 26.47565 \\
\hline & & Max & 694.2895 & 6.479821 & $4.42 \mathrm{E}+08$ & 58.94764 \\
\hline \multirow[t]{5}{*}{19} & Zambia & & & & & \\
\hline & & Mean & 1250.653 & 5.362081 & $-1.75 \mathrm{E}+08$ & 79.18317 \\
\hline & & St. Dev & 292.6578 & 1.853939 & $3.91 \mathrm{E}+08$ & 36.42707 \\
\hline & & Min & 909.5834 & 2.547893 & $-1.22 \mathrm{E}+09$ & 35.28615 \\
\hline & & Max & 1658.823 & 9.418112 & $2.40 \mathrm{O}+\mathrm{O} 8$ & 223.2338 \\
\hline
\end{tabular}

\subsection{Correlation Analysis}

Table 3 below reveals the strength of partial relations linking the four macroeconomic variables under study. It shows a strong positive relationship between GDP FDI, and LPI, but a negative relationship between GDP and ODA. And there is no likelihood of multicoliearity based on the magnitude of the partial correlations. Thus, these correlations validate the choice of these macroeconomic fundamentals in the study.

\begin{tabular}{c|c|c|c|c}
\multicolumn{5}{c}{ Table-3. Correlation analysis. } \\
\hline & GDP & FDI & FPI & ODA \\
\hline GDP & 1 & & & \\
\hline FDI & 0.0386 & 1 & & \\
\hline FPI & 0.20000 & 0.0279 & 1 & \\
\hline ODA & -0.0525 & 0.0181 & -0.0861 & 1 \\
\hline
\end{tabular}

Source: Author's Computation.

\subsection{Analysis of Panel Unit Root}

Determining the stationary of the selected variables is the first step in in using the available data in achieving the objectives of our study.

\begin{tabular}{|c|c|c|c|c|c|c|c|c|c|}
\hline \multirow[t]{3}{*}{ Variables } & \multicolumn{2}{|c|}{ LLC } & \multicolumn{2}{|c|}{ IPS } & \multicolumn{2}{|c|}{ HADRI } & \multicolumn{2}{|c|}{ Breitung } & Remarks \\
\hline & \multicolumn{2}{|c|}{$t^{*}$-Stat } & \multicolumn{2}{|c|}{ Z-Value } & \multicolumn{2}{|c|}{ Z-Stat } & \multicolumn{2}{|c|}{ t-Stat } & \\
\hline & Level & $1^{\text {st }}$ Diff. & Level & $1^{\text {st }}$ Diff. & Level & $1^{\text {st }}$ Diff. & Level & $1^{\text {st }}$ Diff. & \\
\hline GDP & -2.254 & $-3.398 * * * *$ & 5.803 & -7.761 **** & 57.758 **** & $5.850 * * *$ & 10.313 & $-5.094 * * *$ & $\mathrm{I}(1)$ \\
\hline FDI & $-4.501 * * *$ & $-9.148 * * *$ & $-5.703 * * *$ & $-11.533 * * *$ & $12.293 * * *$ & -2.832 & $-4.835^{* * * *}$ & $-12.595 * * *$ & $\mathrm{I}(\mathrm{O})$ \\
\hline FPI & -2.489 & -9.082 & $-6.844 * * *$ & $-12.539^{* * * *}$ & 0.641 & -3.155 & $-5.295^{* * * *}$ & $-10.093 * * *$ & $\mathrm{I}(\mathrm{O})$ \\
\hline ODA & -0.005 & $-6.196 * * *$ & $-2.387 * * *$ & $-11.371 * * *$ & 13.096 **** & -2.434 & $-3.554 * * *$ & $-7.532 * * *$ & $\mathrm{I}(1)$ \\
\hline
\end{tabular}

\subsection{Panel Unit Root}

There are number of techniques in panel data analysis used in the literature in determining the order of integration of a given dataset. Levin et al. (2002) came up with a modified version of the augmented Dickey-Fuller (ADF) unit root test known as Levin et al. (2002) (LLC) unit-root test:

$$
\Delta \mathrm{X}_{\mathrm{it}}=\phi_{\mathrm{it}} \psi_{\mathrm{it}}+\rho \mathrm{X}_{\mathrm{it}-1}+\Sigma \psi_{\mathrm{ij}} \Delta \mathrm{X}_{\mathrm{i}, \mathrm{t}-\mathrm{j}}+\varepsilon_{\mathrm{t}}
$$

Where in Equation 3, фit includes separate deterministic components like fixed effect, trend, or a mixture of fixed effects and trend; $\rho$ the autoregressive parameter; $\xi$ it the error terms; with lag order $\mathrm{n}$.

However, the Levin-Lin-Chu test presumes $\rho$ constant the panel unts but this often experience power degeneration (Breitung, 2001). Im et al. (2003) further develop the Levin-Lin-Chu test by letting $\rho$ to vary over the panel units:

$$
\Delta \mathrm{X}_{\mathrm{it}}=\phi_{\mathrm{it}} \psi_{\mathrm{it}}+\rho_{\mathrm{i}} \mathrm{X}_{\mathrm{it}-1}+\Sigma \psi_{\mathrm{ij}} \Delta \mathrm{X}_{\mathrm{i}, \mathrm{t}-\mathrm{j}}+\varepsilon_{\mathrm{t}}
$$

A new test that rectifies the occurring biasedness in the utilization of Levin et al. (2002) or Im et al. (2003) unitroot test was later developed by Breitung (2001). The difference in magnitude between panel units (N) and periods (T) or the choice an individual deterministic trend in LLC and IPS often leads to this biasedness. Besides, as proposes by Choi (2001) the Fisher test adopts the time series Augmented Dick-Fuller (ADF) and Phillips-Perron (PP) tests as a framework in panel analysis. The Fisher test combines p-value from the unit root test of each series, in lieu of taking the individual test statistics average as proposed by Im et al. (2003). The Hadri (2000) unit root test is premised on the lagrangian multiplier and uses residuals derived from individual ordinary least squared regression on deterministic components to compute the statistics. While LLC, Breitung, IPS and Fisher test the null hypothesis that each series is non stationary across individuals (Ho: $\rho i=0$ ) against the alternative that at least 
one individual in the series is stationary $(\mathrm{H} 1: \rho i<0)$, the Hadri test assumes the opposite (null hypothesis: no unit root against the alternative that some or all series are non-stationary). In addition, the LLC, Breitung and Hadri tests are based on homogeneity in the unit root process ( $\rho i=\rho$ across panels), while the IPS and Fisher tests assume the autoregressive coefficient to be heterogeneous.

As depicted in Table 4, there is clear evidence of stationary of the variables. The LLC, IPS and Breitung tests do not reject the null hypothesis of non-stationary of gross domestic product at level but they rejected it after first difference. While Hadri rejected the null hypothesis at both level and first difference. Thus, concluding that GDP is $\mathrm{I}(1)$ variable that is stationary after first difference. For foreign direct investment (FDI), the LLC, IPS and Breitung tests do reject the null hypothesis of non-stationary at both level and first difference. While Hadri rejected the null hypothesis at both level. Thus, concluding that GDP is I(O) variable that is stationary at level. In addition, for foreign direct investment (FPI), the IPS and Breitung tests do reject the null hypothesis of nonstationary of FPI at both level and after first difference. While the LLC and Hadri do not reject the null hypothesis at both level and first difference. Thus, concluding that FPI is an I(O) variable. Finally, for oversee development assistance (ODA), the LLC, IPS and Breitung tests reject the null hypothesis of non-stationary of oversee development assistance (ODA) after first difference. While Hadri also rejected the null hypothesis at level. Hence, confirming that ODA is $\mathrm{I}(1)$. Therefore, no $\mathrm{I}(2)$ variable is used in the study.

\subsection{Co-Integration Tests}

The discovery of an $\mathrm{I}(1)$ variable in the series calls for a need to examine the presence of long-run equilibrium among the selected variables. The Pedroni (2000) panel and group statistics is used in determining any long-run equilibrium in our model. Pedroni panel tests is centered on the null hypothesis of no co-integration versus the alternative hypothesis of co-integration among the variables. Co-integration tests are dependent on the within dimension analysis, and statistics are estimated independently by summing numerators and denominators along series.

There are four constituents of the panel statistics: a panel-V statistic, a panel-rho, panel-PP and panel ADF statistics which is similar to Phillips-Perron $\rho$ statistics, Phillips- Peron t-statistics and augmented Dickey-Fuller tstatistics in uni-variate time series, respectively. Pedroni group statistics are based on the between dimension approach. The three computable statistics are group-rho, group-PP and group-ADF statistics.

Table-5. Pedroni test of co-integration.

\begin{tabular}{c|c|c}
\hline Test stats & Panel & Group \\
\hline V & -3.502 & \\
\hline Rho & 2.646 & 4.282 \\
\hline T & 1.711 & 2.439 \\
\hline Adf & 5.204 & 7.198 \\
\hline
\end{tabular}

Table 5 displays the outcomes of the co-integration results. In the Pedroni tests, the Schwarz Information Criterion (SIC) with the option of individual intercept with no trend is used to ascertain the appropriate lag length. Evidence of a long-run relations exists among the variables. All the four test components reject the null hypothesis of no co-integration but only for the T-statistic. This simply implies that an equilibrium exist among the variables in the long run and it is evident that there is co-movement among the series in the long run, and the difference among them is stationary. Based on its power, the panel tests appear to be better than the group tests and thus affirm the increasing in efficiency due to pooling of data.

\subsection{Estimation and Discussion of Results}

This section of the research paper is devoted to the estimation and discussion of results. Establishing the empirical relations between the variables is next having discovered that the variables are co-integrated.

The study's baseline estimator the Dynamic fixed effect (DFE) is used in conjunction with the GMM, and the Pooled mean Group (PMG) estimators to obtain the short-run parameter estimates as well as determining the relevance of the findings because each of these estimators has its peculiar merit and arriving at the resulting parameters differently.

Generalized Method of Moment needs that a specific number of moment conditions were set for the model. These moment conditions are functions of the model parameters and the data, such that their expectation is zero at the parameters' true values. The GMM method then minimizes a certain norm of the sample averages of the moment conditions. The GMM estimator is more efficient when $\mathrm{T}<\mathrm{N}$ (Roodman, 2009). To estimate dynamic models with long panels the following estimators Mean Group (MG) estimator, Pooled Mean Group (PMG) estimator and the Dynamic Fixed Effects are used in the literature. The MG estimator by Pesaran and Smith (1995) has to do with estimating $\mathrm{N}$ time-series regressions and taking the average of the coefficients. Using this estimator, the intercepts, slope coefficients, and error variances are all allowed to differ across groups. The PMG estimator by Pesaran et al. $(1997 ; 1999)$ on the other hand, jointly use both pooling and averaging of coefficients. It permits the intercept, short-run coefficients, and error variances to differ across the groups like the MG estimator but constrains the long-run coefficients to be the same across groups. Lastly the DFE estimator, like the PMG estimator, constraints the parameters of the co-integrating matrix to be the same across all panels. This estimator equally restricts the speed of adjustment parameter and the short-run parameters to be the same.

Results of the estimation with that of benchmark models are displayed in Table 6. The DFE provides evidence that foreign flows have impacts on gross domestic product (GDP) in landlocked developing countries (LLDCs). The results as presented in Table 6 shows that net foreign direct investment (FDI), net foreign portfolio investment (FPI) and net official development assistance (ODA) have positive but not significant effects on economic growth at both $1 \%$ and $5 \%$ level of significance. In the short-run, the Dynamic Fixed effect (DFE) estimation technique shows that the negative sign of error correction term shows the overlapping of the series to equilibrium in the long-run. The parameter of the ECMt-1 is found to be (-0.006) for short-run model which 
implies that variation from short-run in real GDP per capita is rectified by $0.6 \%$ every year in the long-run and it is significant at $10 \%$ level.

Meanwhile, the DFE estimator asserts that in the long-run, ODA is the most effective instrument of growth out of the three chosen variables of foreign flows. The slope parameter of net ODA (1.42) reveals that $1 \%$ rise in net (ODA) would raise the real GDP per capita by $1.41 \%$. Net FDI with positive influence on economic growth of the landlocked developing countries is the second significant inflow variable in the analysis. With the parameter of net FDI of 1.134 implies that real GDP per capita increases by $1.13 \%$ for every $1 \%$ increase in net (FDI). This result is partly corroborated by the findings of Shafiq and Ahmad (2016); Pattillo et al. (2002) and Bornschier et al. (1978). Finally, the coefficient of net FPI of 3.26e-10 implies that for net foreign portfolio investment to have appreciable impacts on economic growth of these economies, billions of dollars in net investment is required. That is, for a unit increase in real gross domestic product, 10 billion units of net FPI is needed.

Succinctly, the three estimators used in the robustness tests provide reliable evidence to conclude that foreign flows contribute to growth in the economies of landlocked developing countries (LLDCs). Using the Hausman test for making a choice between the estimates of the PMG and DFE, the coefficient (0.999) is found to be insignificant at the $5 \%$ level. Thus, the analysis is hinged on the DFE estimates, as dynamic fixed effect perform better than the pooled mean group as well as the GMM used as a measure of robustness.

Table-6. Estimation/Robustness.

\begin{tabular}{|c|c|c|c|}
\hline \multirow{3}{*}{ Variable } & GMM & Dynamic fixed effects & Pooled mean group \\
\hline & D. $(\log ($ GDP $)$ & D. $(\log ($ GDP $)$ & D. $(\log ($ GDP $)$ \\
\hline & \multicolumn{3}{|c|}{ Short run } \\
\hline Error Corr & & $\begin{array}{l}-0.00558 \\
(-0.70 * * *)\end{array}$ & $\begin{array}{l}-0.00091 \\
(.00076)\end{array}$ \\
\hline D. $(\log \mathrm{FDI})$ & $\begin{array}{c}0.0050 \\
(0.00226)\end{array}$ & $\begin{array}{c}-0.00179 \\
(-0.69) \\
\end{array}$ & $\begin{array}{l}0.00257 \\
(.00446)\end{array}$ \\
\hline D.(FPI) & $\begin{array}{c}4.96 \mathrm{e}-13 \\
(8.32 \mathrm{e}-13)\end{array}$ & $\begin{array}{c}4.02 \mathrm{E}-13 \\
(0.26)\end{array}$ & $\begin{array}{c}2.26 \mathrm{E}-11 \\
(2.37 \mathrm{e}-11)\end{array}$ \\
\hline D. $(\log$ ODA $)$ & $\begin{array}{c}0.0129 \\
(0.0131) \\
\end{array}$ & $\begin{array}{c}0.00077 \\
(0.14) \\
\end{array}$ & $\begin{array}{c}2.13 \mathrm{E}-05^{* * *} * \\
(.00893)\end{array}$ \\
\hline L.D $(\log$ GDP $)$ & $\begin{array}{c}0.9455^{* * *} * \\
(51.74)\end{array}$ & & \\
\hline Constant & & $\begin{array}{c}0.03656 \\
(0.66)\end{array}$ & $\begin{array}{c}-0.00438 \\
(.0378)\end{array}$ \\
\hline $\operatorname{AR}(1)$ & $-2.59 * * *$ & & \\
\hline $\operatorname{AR}(2)$ & -1.23 & & \\
\hline Instruments & 227 & & \\
\hline \multirow[t]{2}{*}{ Hausman } & & & 0.9998 \\
\hline & \multicolumn{3}{|c|}{ Long run } \\
\hline $\log \mathrm{FDI}$ & & $\begin{array}{c}1.134 \\
(1.666041)\end{array}$ & $\begin{array}{c}3.522 \\
(5.592216)\end{array}$ \\
\hline FPI & & $\begin{array}{c}1.93 \mathrm{E}-10 \\
(3.26 \mathrm{e}-10)\end{array}$ & $\begin{array}{l}-6.01 \mathrm{E}-11 \\
(6.11 \mathrm{e}-10)\end{array}$ \\
\hline $\log \mathrm{ODA}$ & & $\begin{array}{c}1.406 \\
(1.909339)\end{array}$ & $\begin{array}{c}12.505 \\
(19.76189)\end{array}$ \\
\hline
\end{tabular}
respectively.

\section{Conclusion}

This paper has evaluated the impact of foreign flows or what is also known as foreign capital flows on economic growth in the landlocked developing countries with a sample of 19 out of the 32 member-states due to limitation of data using ARDL panel approach with the Dynamic Fixed Effect (DFE) as the baseline estimator for the period of 1995 to 2017.

The findings show that a long-run effect of net foreign direct investment, net official development assistance on economic growth but the net portfolio investment have no any discernible effects on economic growth in the LLDCs. Examining the subject matter from the perspective of LLDCs due to their geographical peculiarity is part of this paper's contribution to the literature. In order to foster economic growth and strengthening these economies on the right trajectory, it is hope that the study's recommendations are given the required attention.

Aggressive pursuit of foreign direct investment and official development assistance would be useful in fostering economic growth in these countries since they show positive though, insignificant impacts on economic growth in the long-run while the impact of portfolio investment is found to be highly negligible on the real GDP per capita. The negative sign of error correction term implies the overlapping of the dynamics model at the steady-state in the long-run. The parameter value of the error correction reveals that the rate at which the model attains the steadystate is highly significant. The findings are pointers for policymakers at both national (government and private investors) and international (donors, foreign investors etc) levels to develop appropriate models that would facilitate economic utilization of the available foreign flows and to minimize the negative impact of over reliance on external debt as well as foreign aids through sound and robust macroeconomic policies usually, trade and industrial policies in conjunction with fiscal and monetary policies. To achieve sustainable economic growth that is the yearnings of the United Nations and other stakeholders, the governments at all levels should provide conducive business environment and institutional framework to attract foreign flows, particularly, FDI and ODA to enhance economic growth in the landlocked developing countries (LLDCs). 


\section{References}

Addison, T., G. Mavrotas and M. McGillivray, 2005. Development assistance and development finance: Evidence and global policy agendas. Journal of International Development: The Journal of the Development Studies Association, 17(6): 819-836.Available at: https://doi.org/10.1002/jid.1243.

Adekunle, W. and M. Sulimon, 2018. A re-examination of the relationship between foreign capital flows and economic growth in Nigeria (No. 87754). University Library of Munich, Germany.

Adeleke, A.I., 2014. FDI-growth nexus in Africa: Does governance matter?. Journal of Economic Development, 39(1): 111-135.Available at: https://doi.org/10.35866/caujed.2014.39.1.005.

Adhikary, B.K., 2011. FDI, trade openness, capital formation, and economic growth in Bangladesh: A linkage analysis. International Journal of Business and Management, 6(1): 16-28.Available at: https://doi.org/10.5539/ijbm.v6n1p16.

Agbloyor, E.K., J.Y. Abor, C.K.D. Adjasi and A. Yawson, 2014. Private capital flows and economic growth in Africa: The role of domestic financial markets. Journal of International Financial Markets, Institutions and Money, 30: 137-152.Available at: https://doi.org/10.1016/j.intfin.2014.02.003.

Akinlo, A.E., 2004. Foreign direct investment and growth in Nigeria: An empirical investigation. Journal of Policy Modeling, 26(5): 627-639

Andraz, J.L., P.M. Gouveia and P.M. Rodrigues, 2009. Modelling and forecasting the UK tourism growth cycle in Algarve. Tourism Economics, 15(2): 323-338.Available at: https://doi.org/10.5367/000000009788254386.

Baltagi, B., 2008. Econometric analysis of panel data. The Atrium, Southern Gate, Chichester, West Sussex PO19 8SQ, England: John Wiley \& Sons.

Boone, P., 1996. Politics and the effectiveness of foreign aid. European Economic Review, 40(2): 289-329.

Bornschier, V., C. Chase-Dunn and R. Rubinson, 1978. Cross-national evidence of the effects of foreign investment and aid on economic growth and inequality: A survey of findings and a reanalysis. American Journal of Sociology, 84(3): 651-683.Available at: https://doi.org/10.1086/226831.

Bräutigam, D.A. and S. Knack, 2004. Foreign aid, institutions, and governance in Sub-Saharan Africa. Economic Development and Cultural Change, 52(2): 255-285.Available at: https://doi.org/10.1086/380592.

Breitung, J., 2001. The local power of some unit root tests for panel data. In Nonstationary panels, panel cointegration, and dynamic panels. Emerald Group Publishing Limited. pp: 161-177.

Burnside, C. and D. Dollar, 2000. Aid, policies, and growth. American Economic Review, 90(4): 847-868.

Chenery, H.B. and A.M. Strout, 1966. Foreign assistance and economic development. The American Economic Review, 56(4): 679-733.

Chimobi, O., 2010. The causal relationship among financial development, trade openness and economic growth in Nigeria. International Journal of Economics and Finance, 2(2): 137.Available at: 10.5539/ijef.v2n2p137.

Choi, I., 2001. Unit root tests for panel data. Journal of International Money and Finance, 20(2): 249-272.Available at: https://doi.org/10.1016/s0261-5606(00)00048-6.

Dalgaard, C.J., H. Hansen and F. Tarp, 2004. On the empirics of foreign aid and growth. The Economic Journal, 114(496): F191F2 16.Available at: https://doi.org/10.1111/j.1468-0297.2004.00219.x.

Durham, J.B., 2004. Absorptive capacity and the effects of foreign direct investment and equity foreign portfolio investment on economic growth. European Economic Review, 48(2): 285-306.Available at: https://doi.org/10.1016/s0014-292 1(02)00264-7.

Gomanee, K., S. Girma and O. Morrissey, 2003. Searching for aid threshold effects. CREDIT Research Paper, No. (03/15).

Gomanee, K., S. Girma and O. Morrissey, 2005. Aid and growth in Sub-Saharan Africa: Accounting for transmission mechanisms. Journal of International Development, 17(8): 1055-1075.Available at: https://doi.org/10.1002/jid.1259.

Gray, K.R., 2003. Foreign direct investment and environmental impacts - Is the debate over? Review of European Community \&amp; International Environmental Law, $11(3):$ 306-313.

Hadri, K., 2000. Testing for stationarity in heterogeneous panel data. The Econometrics Journal, 3(2): 148-161.Available at: https://doi.org/10.1111/1368-423x.00043.

Hansen, H. and F. Tarp, 2000. Aid effectiveness disputed. Journal of International Development, 12(3): 375-398.Available at: https://doi.org/10.1002/(sici)1099-1328(200004)12:3<375::aid-jid657>3.0.co;2-m.

Hoang, T.T., P. Wiboonchutikula and B. Tubtimtong, 2010. Does foreign direct investment promote economic growth in Vietnam? ASEAN Economic Bulletin, 27(3): 295-312.Available at: https://doi.org/10.1355/ae27-3d.

Ilhan, O., 2007. Foreign direct investment-growth nexus: A review of recent literature. International Journal of Applied Econometrics and Quantitative Studies, 4(2): 79-98.

Im, K.S., M.H. Pesaran and Y. Shin, 2003. Testing for unit roots in heterogeneous panels. Journal of Econometrics, 115(1): 53-74.Available at: https://doi.org/10.1016/s0304-4076(03)00092-7.

Jibir, A. and M. Abdu, 2017. Foreign direct investment-growth nexus: The case of Nigeria. European Scientific Journal, 13(1): 304-318.

Karras, G., 2006. Foreign aid and long-run economic growth: Empirical evidence for a panel of developing countries. Journal of International Development: The Journal of the Development Studies Association, 18(1): 15-28.Available at: https://doi.org/10.1002/jid.1187.

Kolawole, B.O., 2013. Foreign assistance and economic growth in Nigeria: The two-gap model framework. American International Journal of Contemporary Research, 3(10): 153-160.

Levin, A., C.-F. Lin and C.-S.J. Chu, 2002. Unit root tests in panel data: Asymptotic and finite-sample properties. Journal of Econometrics, 108(1): 1-24.Available at: https://doi.org/10.1016/s0304-4076(01)00098-7.

Mandilaras, A. and H. Popper, 2009. Capital flows, capitalization, and openness in emerging East Asian economies. Review of International Economics, 17(4): 734-750.Available at: https://doi.org/10.1111/j.1467-9396.2009.00843.x.

Mosley, P., 1986. Aid-effectiveness: The micro-macro paradox. Ids Bulletin, 17(2): 22-27.Available at: https://doi.org/10.1111/j.17595436.1986.mp17002004.x.

Mosley, P., J. Hudson and S. Horrell, 1987. Aid, the public sector and the market in less developed countries. The Economic Journal, 97(387): 616-641.Available at: https://doi.org/10.2307/2232927.

Nyeadi, J.D., O. Atiga and C.A. Atogenzoya, 2014. The impact of exchange rate movement on export: Empirical evidence from Ghana. International Journal of Academic Research in Accounting, Finance and Management Sciences, 4(3): 41-48.Available at: https://doi.org/10.6007/ijarafms/v4-i3/980.

Obiechina, M. and E. Ukeje, 2013. Economic growth, capital flows, foreign exchange rate, export and trade openness in Nigeria. International Journal of Economics and Management Sciences, 2(9): 1-13.

Orji, A., A.S. Uche and E.A. Ilori, 2014. Foreign capital inflows and growth: An empirical analysis of WAMZ experience. International Journal of Economics and Financial Issues, 4(4): 971-983.

Ouattara, B., 2006. Aid, debt and fiscal policies in Senegal. Journal of International Development: The Journal of the Development Studies Association, 18(8): 1105-1122.Available at: https://doi.org/10.1002/jid.1282.

Pattillo, C.A., H. Poirson and L.A. Ricci, 2002. External debt and growth (No. 2002-2069). International Monetary Fund.

Pedroni, P., 2000. Fully modified OLS for heterogeneous cointegrated panels. In nonstationary panels, panel cointegration, and dynamic panels. Bingley: Emerald Group Publishing Limited. pp: 93-130.

Pesaran, M.H., Y. Shin and R.P. Smith, 1997. Pooled estimation of long-run relationships in dynamic heterogenous panels. DAE Eorking Papers Amalgamated Series, No. 9721.

Pesaran, M.H., Y. Shin and R.P. Smith, 1999. Pooled mean group estimation of dynamic heterogeneous panels. Journal of the American Statistical Association, 94(446): 62 1-634.Available at: https://doi.org/10.1080/0162 1459.1999.10474156.

Pesaran, M.H. and R. Smith, 1995. Estimating long-run relationships from dynamic heterogeneous panels. Journal of Econometrics, 68(1): 79-1 13.Available at: https://doi.org/10.1016/0304-4076(94)0 1644-f.

Quartey, P., 2005. Innovative ways of making aid effective in Ghana: Tied aid versus direct budgetary support. Journal of International Development, 17(8): 1077-1092.Available at: https://doi.org/10.1002/jid.1260.

Roodman, D., 2009. How to do xtabond2: An introduction to difference and system GMM in Stata. The Stata Journal, 9(1): 86-136.Available at: https://doi.org/10.1177/1536867x0900900106.

Rothstein, R.L., 2015. Global bargaining: UNCTAD and the quest for a new international economic order. Princeton University Press. 
Shafiq, U.R. and H.K. Ahmad, 2016. The impact of foreign capital inflows on economic growth: Pooled mean group analysis for developing countries. Pakistan Economic and Social Review, 54(2): 191-203.

Shen, C.-H., 2010. What makes international capital flows promote economic growth? An international cross-country analysis. Scottish Journal of Political Economy, 57(5): 515-546.

Todaro, M.P. and S.C. Smith, 2012. Economic development. 11th Edn., USA: Pearson Education Incorporated.

Ugwuegbe, S.U., I. Okafor and C. Akarogbe, 2016. Effect of external borrowing and foreign aid on economic growth in Nigeria. International Journal of Academic Research in Business and Social Sciences, 6(4): 155-175.Available at: https://doi.org/10.6007/ijarbss/v6-i4/2087.

WDI, 2018. World development indicator. Washington DC: The World Bank Group. 